\title{
MINIMISASI SULFUR BATUBARA DENGAN SODIUM KARBONAT UNTUK BAHAN BAKU BRIKET
}

\author{
Oleh : \\ Haspiadi ${ }^{4}$
}

\begin{abstract}
Coal is a raw material especially in the "coal briquet" industry. Coal is a solid with a sulfur content up to $5 \%$, and sulfur has negative effect at exhaust emission.

The main objective of this study is to remove sulfur from coal after the coal crushed and screened and then soluted by sodium carbonate $\left(\mathrm{Na}_{2} \mathrm{CO}_{3}\right)$ in various concentration. The results of analyzes of sulfur content which has been done, show that the concentration of sodium carbonate has correlation to change sulfur content in coal. An optimum concentration was obtained in $2,5 \%$ sodium carbonate which can remove $8,29 \%$ sulfur contained in coal.
\end{abstract}

Keywords : Coal, coal briquet, sulfur content and sodium carbonate $\left(\mathrm{Na}_{2} \mathrm{CO}_{3}\right)$

\section{PENDAHULUAN}

otensi sumber daya batubara Indonesia diperkirakan mencapai 57,85 miliar

Iton. Jumlah tersebut terdiri dari 20,53 miliar ton dikategorikan sebagai yang terindikasi (indicated) dan 12,47 miliar ton dikategorikan sebagai sumber daya terukur (measured). Sebanyak 6,98 miliar ton di antaranya termasuk ke dalam kategori cadangan (reserve) yang siap ditambang (miniable). Sekitar $52,15 \%$ cadangan batubara Indonesia tersebar di Kalimantan dan sisanya tersebar di Sumatera, Jawa, Sulawesi dan Papua (Anonim, 2007).

Batu bara sebagai sumber energi mempunyai andil yang cukup penting dalam menunjang kebutuhan energi. Pemanfaatannya dapat langsung digunakan sebagai bahan bakar maupun dalam bentuk lain melalui proses tertentu, seperti proses karbonisasi untuk mendapatkan kokas, gasifikasi untuk mendapatkan gas dan liquifikasi untuk mendapatkan cairan serta produk briket batubara sendiri.

Dewasa ini dengan sulitnya masyarakat mendapatkan bahan bakar minyak, maka bahan bakar dari batubara merupakan primadona sebagai bahan bakar pengganti, bahkan pemerintah telah menggiatkan untuk penggunaan briket khususnya masyarakat menengah ke bawah. Namun penggunaan briket batubara sebagai energi pengganti ini belum sepenuhnya mendapatkan respon yang positif dari masyarakat.

Kurangnya minat masyarakat dikarenakan beberapa faktor, diantaranya emisi gasgas yang timbul selama proses pembakaran yang disebabkan oleh bahan-bahan organik dan anorganik sebagai material penyusunnya. Salah satu contoh adalah belerang dalam bentuk pirit, markasit dan sulfat, yang terdapat dalam batubara dengan sifat inert serta berbahaya terhadap makhluk hidup dan lingkungan.

Kandungan sulfur batubara khususnya di Kalimantan Timur sebagai contoh umumnya berkisar antara $0,05 \%$ sampai dengan $5,00 \%$. Dalam proses pembakaran sulphur akan terlepas ke udara atmosfer dalam bentuk sulfur dioksida dan sulfur trioksida

*) Peneiti Bantisiand industri Samaninda 
yang bersifat tidak berwarna dan menyebabkan rasa pada konsentrasi $0,783 \mathrm{mg} / \mathrm{Nm}^{3} \mathrm{~s} / \mathrm{d}$ $2,612 \mathrm{mg} / \mathrm{Nm}^{3}$.

Beberapa penelitian terdahulu telah dilakukan untuk pemurnian batubara, khususnya penurunan kadar sulfur dengan memecah batubara menjadi bagian terkecil kemudian dicuci namun tidak semua sulfur terlepas karena sulfur tersebut terikat secara kimia dengan molekul karbon batubara. Beberapa proses lain telah dicoba dengan mencampur batubara dengan bahan kimia namun pada kenyataannya belum memberikan hasil yang optimal (Anonim, 2000).

Penelitian serupa telah dilakukan untuk pemurnian batubara dengan proses pirolisis menggunakan pelarut $n$-heksane, toluene dan piridin disamping biaya yang mahal hasilnya juga tidak signifikan terhadap penurunan sulfur (Bambang Setiaji, 2004). Demikian pula percobaan penurunan sulfur batubara dengan cara menambahkan kapur walaupun berpengaruh terhadap penurunan, namun terhadap nilai kalori justru turun dari $5926 \mathrm{Kkal} / \mathrm{Kg}$ menjadi $5701 \mathrm{Kkal} / \mathrm{Kg}$ (Anonim 2006).

Oleh karena itu untuk dapat mengoptimalkan atau kemungkinan diperolehnya metode yang lebih baik untuk penurunan sulfur batu bara sehingga dihasilkan briket batubara ramah lingkungan, maka melalui penelitian ini telah dilakukan proses penurunan atau minimisasi sulfur batubara dengan proses kimia menggunakan sodium karbonat dalam berbagai kombinasi perlakukan.

\section{BAHAN DAN METODE \\ Bahan dan Peralatan}

Bahan yang digunakan terdiri dari sodium karbonat $\left(\mathrm{Na}_{2} \mathrm{CO}_{3}\right)$, dan jenis peralatan terdiri dari tangki sirkulasi, aerator, timbangan analitik, $\mathrm{pH}$-meter, $\mathrm{DO}$-meter dan crusher.

\section{Metode}

Penelitian dilakukan dengan skala laboratorium diawali pemilihan batubara bersulfur tinggi sesuai hasil survey lapangan. Selanjutnya analisa kwantitatif sulfur batubara, kemudian menetapkan rancangan komposisi atau perbandingan dari bahan kimia pengikat sulfur dengan jumlah sulfur dalam batubara yang akan diolah. Adapun parameter akhir yang akan diamati adalah besarnya penurunan sulfur batubara.

\section{Pemilihan Jenis Batubara}

Pemilihan batubara yang digunakan didasari oleh nilai sulfur yang dihitung sebagi Total Sulfur (TS), tanpa spesifik nama dan lokasi tambang. Pengambilan sampel dilakukan pada satu titik di areal tambang untuk menghindari besarnya fluktuasi sebaran sulfur, kemudian diaduk sehingga benar-benar homogen. Selanjut digiling dan diambil dengan cara quartering untuk uji pendahuluan sebanyak $\pm 2 \mathrm{Kg}$ dengan metode ASTM D 3177.

\section{Pengaturan Komposisi}

Pengaturan komposisi dari setiap formula bahan kimia yang digunakan berdasarkan basis perhitungan kadar sulfur dalam batubara awal sebagai berikut:

Basis perhitungan $1 \mathrm{Kg}$ batubara :

mols

mol Sulfur dalam batubara $=1000 \mathrm{~g} \times$ Kadar Sulfur $\times \frac{\text { BM Sulfur }}{\text { BM }}$

Berdasarkan reaksi yang terbentuk:

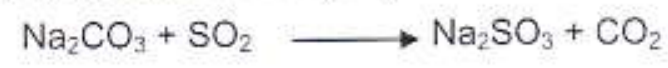

$\mathrm{Mol} \mathrm{Na} \mathrm{CO}_{3}=$ mol Na $\mathrm{CO}_{3} \times$ mol sulfur dalam $1000 \mathrm{~g}$ 


$$
\begin{aligned}
& \text { jadi : } \frac{\mathrm{Mol} \mathrm{Na}_{2} \mathrm{CO}_{3}}{\mathrm{Kg} \text { Batubara }} \times \mathrm{BM} \mathrm{Na}_{2} \mathrm{CO}_{3}=\frac{0,625 \mathrm{~mol}}{\mathrm{Kg} \text { batubara }} \times 83,99 \mathrm{~g} / \mathrm{mol} \\
& =52 \mathrm{~g} \mathrm{Na}_{2} \mathrm{CO}_{3} / \mathrm{Kg} \text { Batubara }
\end{aligned}
$$

Berdasarkan perhitungan di atas maka untuk $2,5 \mathrm{Kg}$ batubara diperiukan $130 \mathrm{~g}$ $\mathrm{Na}_{2} \mathrm{CO}_{3}$, sehingga dibuat rancangan sebanyak 8 (delapan) konsentrasi yang berbeda berdasarkan berat sodium karbonat, $\mathrm{Na}_{2} \mathrm{CO}_{3}$ terhadap volume air jenuh udara (10 Liter dihitung atas dasar volume kolom) sebagaimana pada table 1.

Tabel 1. Rancangan Komposisi Sodium Karbonat, $\mathrm{Na}_{2} \mathrm{CO}_{3}$

\begin{tabular}{|c|c|c|c|c|c|}
\hline $\begin{array}{c}\text { Kode } \\
\text { Sampel }\end{array}$ & $\begin{array}{c}\text { Berat } \\
\text { Batubara } \\
\mathrm{Kg}\end{array}$ & $\begin{array}{c}\text { Konsentrasi } \\
\mathrm{Na}_{2} \mathrm{CO}_{3}(\%)\end{array}$ & $\begin{array}{c}\text { Laju Alir } \\
\text { (L/Menit) }\end{array}$ & $\begin{array}{c}\text { Kadar } \\
\text { Sulfur } \\
(\%)\end{array}$ & $\begin{array}{c}\text { Rata- } \\
\text { rata } \\
\text { Sulfur } \\
(\%)\end{array}$ \\
\hline A & 2,5 & 0,05 & 0,25 & & \\
\hline B & 2,5 & 0,1 & 0,25 & & \\
\hline C & 2,5 & 0,5 & 0,25 & & \\
\hline D & 2,5 & 1,0 & 0,25 & & \\
\hline E & 2,5 & 1,5 & 0,25 & & \\
\hline F & 2,5 & 2,0 & 0,25 & & \\
\hline G & 2,5 & 2,5 & 0,25 & & \\
\hline H & 2,5 & 3,0 & 0,25 & & \\
\hline
\end{tabular}

\section{Tahapan Percobaan}

Tahapan percobaan sebagaimana diagram alir pada gambar 1 dimana kontak batubara dan larutan $\mathrm{Na}_{2} \mathrm{CO}_{3}$ berlangsung dalam tabung dengan laju alir keluaran diatur $0,25 \mathrm{~L} / \mathrm{menit}$.

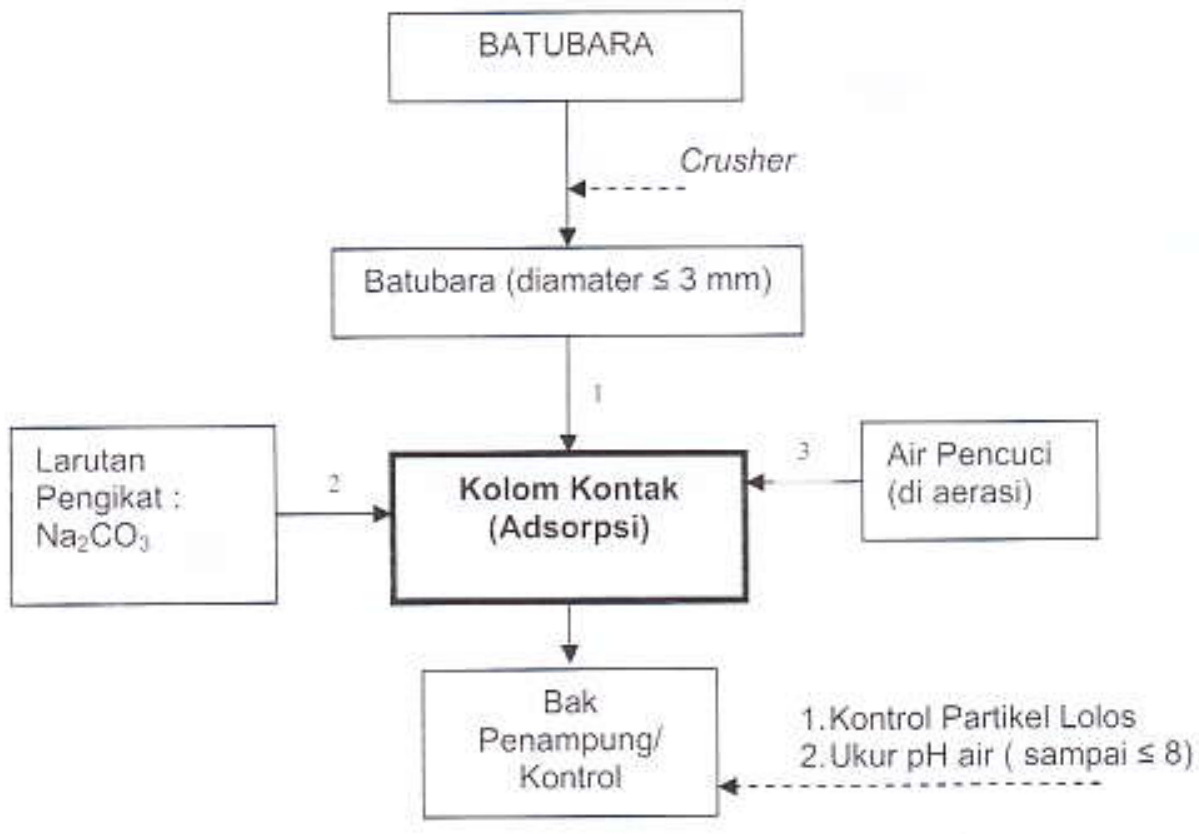

Gambar 1. Diagram Alir Proses Pengolahan Batubara 


\section{Evaluasi Hasil Percobaan}

Pengaruh penggunaan bahan kimia untuk penurunan kadar sulfur total dalam batubara dievaluasi dengan Analisa Sidik Ragam (Ansira), serta menghitung besarnya persentase penurunannya.

\section{HASIL DAN PEMBAHASAN}

\section{Percobaan Pendahuluan}

Jenis batubara yang digunakan dalam penelitian ini diambil dari salah satu perusahaan tambang di Kalimantan Timur dengan kualitas batubara bersulfur tinggi yaitu $2,41 \%$. Pemilihan batubara bersulfur tinggi dimaksudkan untuk memudahkan pengontrolan besarnya kisaran penurunan sulfur yang dilihat dari persentasenya,

Sedangkan pemilihan sodium karbonat, $\mathrm{Na}_{2} \mathrm{CO}_{3}$ karena dari beberapa teori menyatakan bahwa sodium karbonat yang bereaksi dengan sulphur dapat dipresipitasi menjadi sodium sulfat dan airnya dapat digunakan lagi sebagai pereaksi pada scruber (de Nevers N.,1995).

Proses pengikatan sulfur dari batubara adalah proses adsorpsi, dimana permukaan material kontak dengan larutan yang cenderung terakumulasi pada lapisan permukaan. Sebagaimana dijelaskan oleh Eckenfelder, 1989 bahwa adsorpsi terjadi secara fisika dari kondensasi molekul di dalam kapiler padatan dan secara umum laju adsorpsi dikontrol oleh laju diffusi molekul larutan dalam lubang kapiler dari partikel batubara.

Hasil percobaan pendahuluan menunjukkan bahwa dengan konsentrasi $1,5 \%$ sodium karbonat $\left(\mathrm{Na}_{2} \mathrm{CO}_{3}\right)$ efektif menurunkan sulfur batubara sebesar $5,39 \%$. Untuk tahap selanjutnya dilakukan penelitian lanjutan menggunakan sodium karbonat dengan berbagai konsentrasi, sedangkan kondisi teknis operasional pengolahan tidak divariasikan yaitu kelarutan oksigen ditetapkan lebih besar atau sama dengan $7 \mathrm{mg} / \mathrm{L}$ sebagaimana dijelaskan oleh Adel. L. Pfeil (2006) bahwa penambahan udara dalam air proses atau aerasi dapat mereduksi sulfur sebagai Hidrogen Sulfida walaupun tidak selamanya mencapai nilai yang nihil, sedangkan laju alir larutan untuk kontak dengan batubara ditetapkan sebesar 0,25 Liter/menit atas dasar jumlah batubara sebanyak $2000 \mathrm{~g}$ yang dapat kontak dengan larutan secara merata dalam tabung.

Peralatan yang digunakan dibuat secara konvensional terdiri dari tabung, pompa air dan bak suplai larutan dan bak penampung larutan serta aerator sebagaimana Gambar 2. Sistem kerja alat tersebut adalah larutan dipompakan ke dalam kolom dan dikontakkan dengan batubara yang telah dihaluskan dengan diameter rata-rata $\leq 3 \mathrm{~mm}$ sesuai diameter bahan baku briket. Untuk jelasnya dapat dilihat diagram alir pada gambar 1.

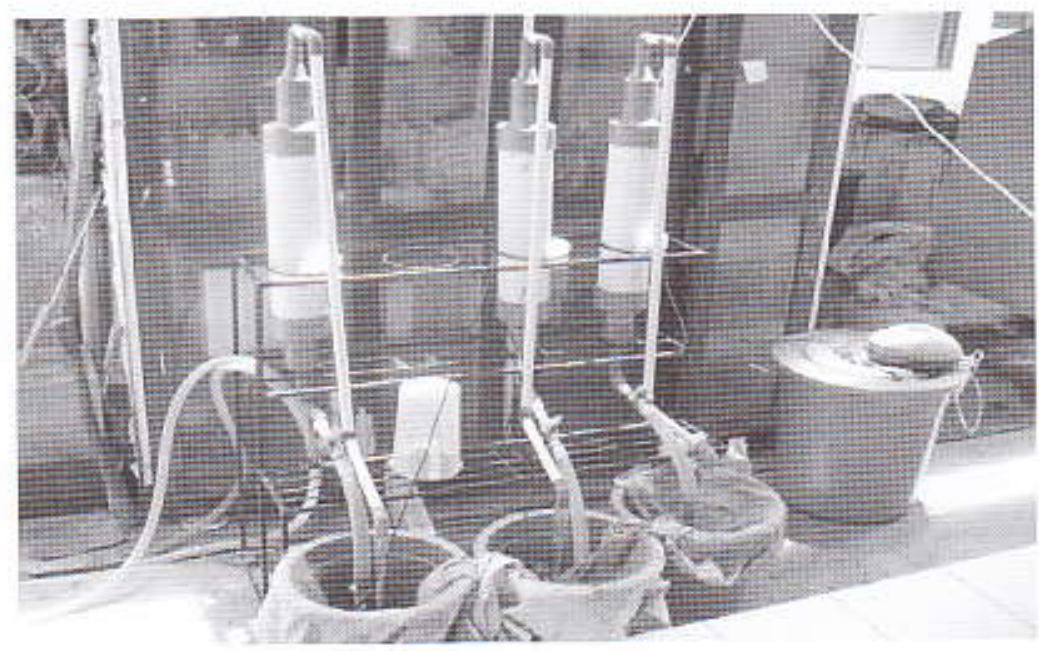

Gambar 2. Alat Pengolah Batubara Secara Konvensional 


\section{Percobaan Lanjut}

Hasil yang diperoleh dalam penelitian dengan sodium karbonat secara umum dapat dilihat pada tabel 2 di bawah.

Tabel 2. Sulfur Batubara Hasil Pengolahan Menggunakan Sodium Karbonat

\begin{tabular}{|c|c|c|c|c|c|c|}
\hline $\begin{array}{c}\text { Kode } \\
\text { Sampel }\end{array}$ & $\begin{array}{c}\text { Berat } \\
\text { Batubara } \\
(\mathbf{K g})\end{array}$ & $\begin{array}{c}\text { Kons. } \\
\mathrm{Na}_{2} \mathbf{C O}_{3} \\
(\%)\end{array}$ & $\begin{array}{c}\text { Laju Alir } \\
\text { (L/menit) }\end{array}$ & $\begin{array}{c}\text { Sulfur } \\
\text { Rata-rata } \\
\text { sebelum } \\
(\%)\end{array}$ & $\begin{array}{c}\text { Sulfur } \\
\text { Rata-rata } \\
\text { setelah } \\
(\%)\end{array}$ & $\begin{array}{c}\text { Penur- } \\
\text { unan } \\
\text { Sulfur } \\
(\%)\end{array}$ \\
\hline A & 2,5 & 0,05 & 0,25 & 2,41 & 2,33 & 3,32 \\
\hline B & 2,5 & 0,1 & 0,25 & 2,41 & 2,32 & 3,73 \\
\hline C & 2,5 & 0,5 & 0,25 & 2,41 & 2,31 & 4,15 \\
\hline D & 2,5 & 1,0 & 0,25 & 2,41 & 2,29 & 4,98 \\
\hline E & 2,5 & 1,5 & 0,25 & 2,41 & 2,28 & 5,39 \\
\hline F & 2,5 & 2,0 & 0,25 & 2,41 & 2,23 & 7,47 \\
\hline G & 2,5 & 2,5 & 0,25 & 2,41 & 2,21 & 8,29 \\
\hline H & 2,5 & 3,0 & 0,25 & 2,41 & 2,21 & 8,30 \\
\hline
\end{tabular}

Dari data tersebut diatas dihitung dengan Analisa Sidik Ragam untuk mengetahui sejauh mana pengaruh penggunaan sodium karbonat terhadap penurunan sulfur, dan diketahui bahwa hasil uji $F$ menunjukkan penggunaan sodium karbonat berpengaruh sangat nyata dalam menurunkan sulfur batubara.

Dilanjutkan dengan uji BNT, maka pada taraf uji $5 \%$ pengaruh penggunaan sodium karbonat terhadap penurunan sulfur batubara dengan konsentrasi $2,5 \%$ berbeda nyata dengan konsentrasi lainnya dan tidak berbeda nyata dengan konsentrasi $3,0 \%$. Demikian pula dengan uji pada taraf $1 \%$ pengaruh penggunaan sodium karbonat terhadap penurunan sulfur untuk konsentrasi $2,5 \%$ berbeda sangat nyata dengan konsentrasi lainnya kecuali konsentrasi $3,0 \%$ berbeda sangat tidak nyata. Dengan demikian perlakuan terbaik (tertinggi) dari ke delapan konsentrasi yang berbeda adalah perlakuan $2,5 \% \mathrm{Na}_{2} \mathrm{CO}_{3}$, sebagaimana data pada tabel 3 .

Tabel 3. Hasil Uji BNT Pengaruh $\mathrm{Na}_{2} \mathrm{CO}_{3}$ Terhadap Penurunan Sulfur Batubara

\begin{tabular}{|c|c|c|c|c|}
\hline $\begin{array}{c}\text { Konsentrasi } \\
\mathrm{Na}_{2} \mathrm{CO}_{3}\end{array}$ & $(\%)$ & $\begin{array}{c}\text { Rata-rata } \\
\text { Penurunan } \\
\text { Sulfur (\%) }\end{array}$ & BNT $0,05=0,012$ & BNT 0,0 t $=0,016$ \\
\hline 0 & $\mathrm{H} 0$ & 2,41 & $f$ & $f$ \\
\hline 0,05 & $\mathrm{H} 1$ & 2,33 & $e$ & $\mathrm{e}$ \\
\hline 0,1 & $\mathrm{H} 2$ & 2,32 & $d e$ & $d$ \\
\hline 0.5 & $\mathrm{H} 3$ & 2,31 & $d$ & $c$ \\
\hline 1,0 & $\mathrm{H} 4$ & 2,29 & $c$ & $c$ \\
\hline 1,5 & $\mathrm{H} 5$ & 2,28 & $c$ & $b$ \\
\hline 2,0 & $\mathrm{H} 6$ & 2,23 & $b$ & $\mathrm{c}$ \\
\hline 2,5 & $\mathrm{H} 7$ & 2,21 & $\mathrm{a}$ & $\mathrm{a}$ \\
\hline 3,0 & $\mathrm{H}$ & 2,21 & $\mathrm{a}$ & $\mathrm{c}$ \\
\hline
\end{tabular}

Keterangan: Angka-angka yang dikuti oleh huruf yang sama berarti berbeda tidak nyata $5 \%$ $(0,012)$ dan tidak berbeda nyata $1 \%(0,016)$

Selain uji $F$ juga dilakukan perhitungan besarnya persentase setiap penurunan konsentrasi dengan sodium karbonat $\left(\mathrm{Na}_{2} \mathrm{CO}_{3}\right)$, dari delapan variasi konsentrasi yang menunjukkan kecenderung meningkat sebagaimana kenaikan konsentrasi. Namun bila dibandingkan dengan kandungan sulfur tanpa perlakukan sebesar $2,41 \%$ persentase penurunan masih relatif kecil.

Perhitungan persentase penurunan untuk sampel dengan kode $A$ dari kandungan sulfur awal sebesar $2,41 \%$ dengan menggunakan larutan sodium karbonat $0,05 \%$ mampu menurunkan sulfur menjadi $2,33 \%$ atau persentase penurunan sebesar $3,32 \%$, 
demikian pula untuk sampel kode B dengan kenaikan konsentrasi $0,1 \%$ larutan sodium karbonat persentase penurunan hanya berkisar 3,52 \% yaitu sulfur menjadi $2,32 \%$ saja. Berbeda dengan sampel $\mathrm{C}$ untuk konsentrasi $0,5 \%$ persentase penurunan lebih tinggi dibandingkan dengan sampel $A$ dan $B$ yaitu sebesar $4,15 \%$, yaitu dari batubara dengan kandungan sulfur $2,41 \%$ menjadi $2,31 \%$.

Selanjutnya penggunaan larutan sodium karbonat 1,0\% diperoleh persentase penurunan sebesar $5,18 \%$ dari kandungan batubara awal $2,41 \%$ menjadi $2,29 \%$ sulfur. Hal yang sama juga terjadi untuk penggunan konsentrasi $1,5 \%$ larutan sodium karbonat persentase penurunan hanya sebesar 5,39\% atau kandungan sulfur total turun menjadi $2,28 \%$.

Kenaikan terus ditunjukkan dengan kenaikan konsentrasi larutan penyerap yaitu untuk konsentrasi sodium karbonat 2,0\% kandungan sulfur batubara menjadi $2,23 \%$ atau persentase penurunan sebesar $7,68 \%$. Selanjutnya untuk kenaikan konsentrasi larutan sebesar $2,5 \%$ persentase penurunan sulfur juga naik sebesar $8,29 \%$ atau dari $2,41 \%$ sulfur awal menjadi $2,21 \%$.

Namun untuk konsentrasi 3,0\% larutan penyerap sodium karbonat persentase penurunan cenderung tetap yaitu $8,30 \%$. Kecenderungan perubahan yang tetap dari persentase penurunan menggunakan konsentrasi larutan sodium karbonat $2.5 \%$ dan $3,0 \%$ dapat disebabkan oleh tingkat penyerapan larutan terhadap sulfur menjadi jenuh atau dimungkinkan oleh jenis sulfur batubara yang terikat dalam batubara, sebagaimana diketahui bahwa sulfur dalam batubara terdiri dari pirit sulfur, sulfat sulfur dan organik sulfur. Hubungan antara konsentrasi $\mathrm{Na}_{2} \mathrm{CO}_{3}$ dengan laju persentase penurunan sulfur dapat dilihat pada gambar 3 .

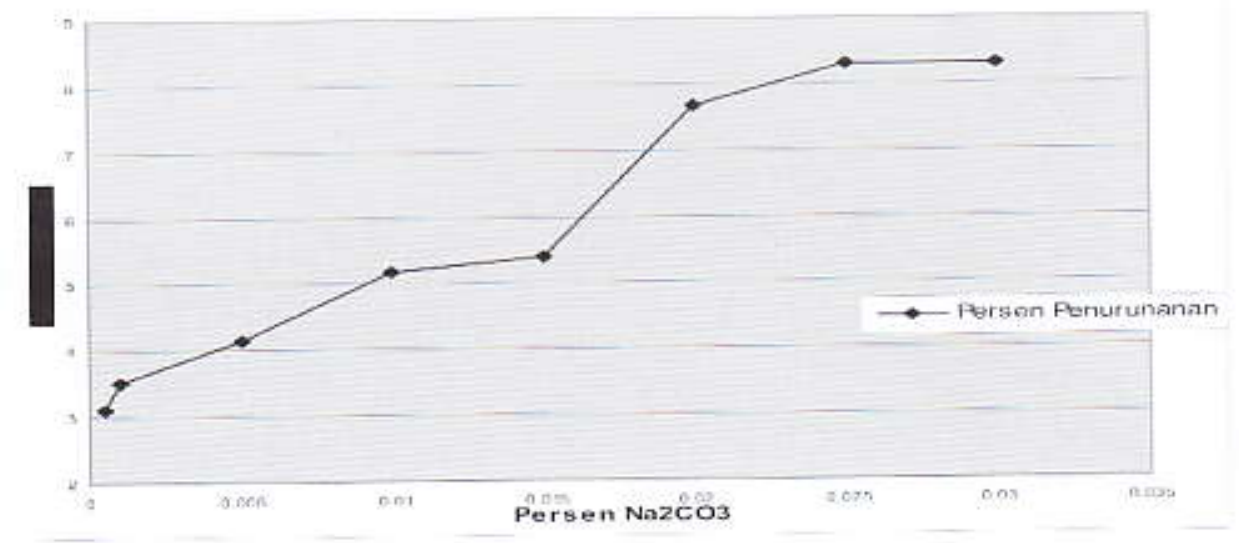

Gambar 3. Hubungan Konsentrasi $\mathrm{Na}_{2} \mathrm{CO}_{3}(\%)$ Terhadap Persentase Penurunan Sulfur

Kecenderungan penurunan sulfur dalam batubara dari berbagai perlakukan yang relatif kecil dapat dimungkinkan oleh beberapa faktor sebagaimana yang ditunjukkan hasil uji terhadap kadar sulfat $\left(\mathrm{SO}_{4}{ }^{2-}\right)$ dan sulfit $\left(\mathrm{SO}_{3}{ }^{-}\right)$dalam air. Hasil uji larutan proses pengolahan untuk nilai sulfat dari kadar air sebelum digunakan dan setelah digunakan untuk menyerap sulfur dalam batubara kenaikannya cukup tinggi. Sehingga dari analisa ini dapat diperkirakan bahwa sulfur yang terikat oleh larutan adalah sulfur sebagai sulfat sulfur sebagaimana data pada tabel 4 . 
Tabel 4. Kadar Sulfat dan Sulfit dalam Air Sisa Pengolahan

\begin{tabular}{|c|c|c|c|}
\hline No. & Konsentrasi $\mathrm{Na}_{2} \mathrm{CO}_{3}$ & $\begin{array}{c}\text { Sulfat, } \mathbf{S O}^{2-} \\
(\mathbf{m g} / \mathbf{L})\end{array}$ & Sulfit, $\mathrm{SO}^{-2}$ (mg/L) \\
\hline 1. & 0,05 & 138 & 6.0 \\
\hline 2. & 0,1 & 150 & 6,8 \\
\hline 3. & 0,5 & 163 & 7,2 \\
\hline 4. & 1,0 & 258 & 7,6 \\
\hline 5. & 1,5 & 263 & 8,0 \\
\hline 6. & 2,0 & 585 & 16,0 \\
\hline 7. & 2,5 & 615 & 16,0 \\
\hline 8. & 3,0 & 595 & 16,8 \\
\hline
\end{tabular}

Korelasi yang ditunjukkan kadar sulfur batubara yang diindikasikan dengan kandungan sulfat $\left(\mathrm{SO}_{4}{ }^{2-}\right)$ dalam air sisa serapan mengalami kenaikan seiring dengan kenaikan konsentrasi $\mathrm{Na}_{2} \mathrm{CO}_{3}$ dari $3,42 \mathrm{mg} / \mathrm{L}$. Kenaikan konsentrasi sulfat berkorelasi dengan naiknya persentase penurunan sulfur dari $3,11 \%$ untuk konsentrasi $\mathrm{Na}_{2} \mathrm{CO}_{3}$ $0,05 \%$ seterusnya hingga konsentrasi $2,5 \% \mathrm{Na}_{2} \mathrm{CO}_{3}$ persentase penurunan menjadi 8,29 $\%$. Namun pada konsentrasi $3 \%$ larutan penyerap kadar sulfat dalam air sedikit turun.

Untuk nilai sulfit dalam air sebelum digunakan TTD (Tidak Terdeteksi) juga mengalami kenaikan, namun kenaikannya relatif kecil dibandingkan dengan konsentrasi sulfat, adanya sulfit ini dapat disebabkan oleh hasil oksidasi sulfida yang pada umumnya berbentuk pirit $\left(\mathrm{FeS}_{2}\right)$ bersinggungan dengan udara membentuk sulfur trioksida sebagaimana reaksi:

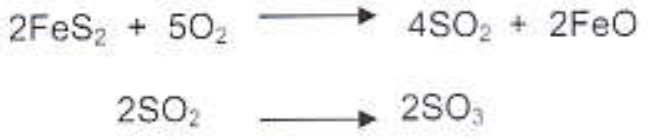

Selain itu pula kemungkinan turunnya kadar sulfur total sebagai pirit sulfur dimungkinkan oleh diameter batubara sebagaimana teori yang dikemukakan oleh de Nevers, 1995 dalam bukunya bahwa pirit sulfur dapat dihilangkan dengan cara penghancuran batubara dalam ukuran yang kecil, dimana sebagian besar pirit yang ada dalam bentuk partikel pirit, sehingga dengan ukuran batubara $\leq 3 \mathrm{~mm}$ yang digunakan dalam penelitian ini memungkinkan pirit sulfur akan terlepas.

Demikian pula teori yang menyatakan bahwa beberapa sulfur yang ada sebagai bintik kecil dibatubara disebut sebagai pyritic sulfur karena adanya reaksi dengan besi menjadi bentuk iron pyrite selain itu dikenal juga sebagai foll's good yang dapat dicuci dari batubara dengan bahan kimia (Anonim, 2006).

Dari ketiga jenis sulfur diatas kecenderungan yang sulit terlepas dari batubara adalah organik sulfur yang benar-benar terikat dengan molekul karbon batubara. Walaupun dari beberapa penelitian terdahulu telah dilakukan dengan pencucian namun pengaruhnya sangat kecil dan justru terbukti membutuhkan biaya mahal. Oleh karena itu beberapa penelitian saat ini masih dilakukan untuk dapat menemukan metode yang sesuai oleh para ahli (Anonim 2006). 


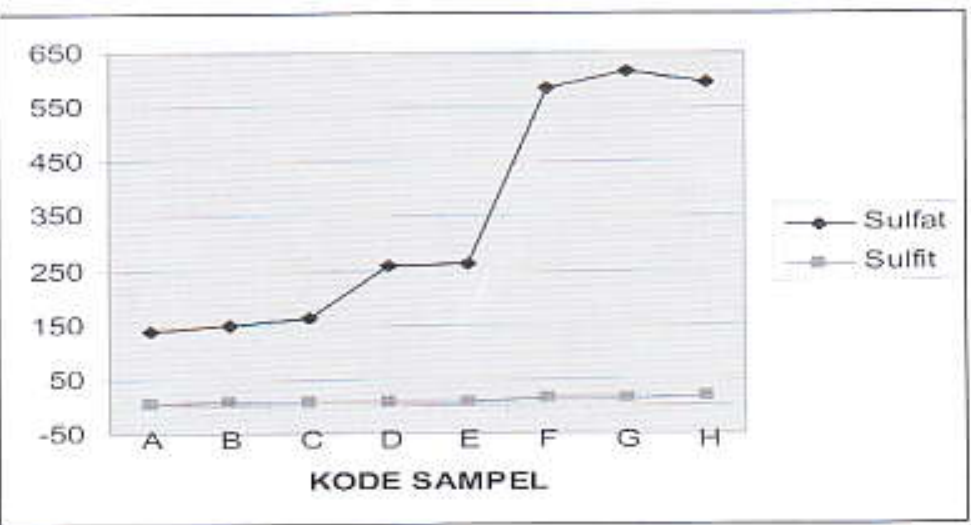

Gambar 4. Hubungan Konsentrasi Sulfat dan Sulfit dalam Air Sisa Pengolahan

Dari ketiga indikator sulfur batubara yang terlepas maka sulfur sebagai sulfat sulfur yang diindikasikan dengan kelarutan sulfat dalam air cukup tinggi memungkinkan alasan bahwa jenis sulfur yang terlepas dominan berupa sulfat sulfur saja. Sebagai mana diuraikan oleh de Nevers N., 1995 dalam bukunya "Air Pollution Control Engineering" bahwa sulfat sulfur dalam batubara merupakan hasil reaksi antara bangkai kayu dan air tanah yang menembusnya sebagai saringan, mengandung sejumlah sulfat terlarut umumnya dalam bentuk kalsium sulfat, sebagai mana reaksi :

Sulfat + reducing agent (bangkai kayu) + bakteri $\longrightarrow$ air + rantai sulfur

Bila dilihat secara keseluruhan dari delapan variasi konsentrasi $\mathrm{Na}_{2} \mathrm{CO}_{3}$, persentase penurunan sulfur atau jumlah sulfur yang hilang dari batubara masih kecil. Namun bila dibandingkan dengan batubara berkonsentrasi kurang dari $1 \%$ minimal dapat mengurangi polutan yang diemisikan sulfur dalam bentuk Sulfur dioksida $\left(\mathrm{SO}_{2}\right)$ saat berlangsung proses pembakaran, dimana rata-rata sulfur dioksida yang teremisikan dari penggunaan batubara sebagai bahan bakar pada Pembangkit Listrik Tenaga Uap sesuai KEP-13/MenLH/3/1995 maksimum diperbolehkan $750 \mathrm{mg} / \mathrm{m}^{3}$.

Selain dilakukan analisa penurunan sulfur juga dilakukan pengujian terhadap pengaruh penggunaan sodium karbonat terhadap nilai kalor batubara sebagai kontrol. Rata-rata nilai kalori sesudah diolah lebih tinggi dibandingkan sebelum diolah yaitu 5519 $\mathrm{kal} / \mathrm{gram}$ yang sebelumnya hanya $5218 \mathrm{kal} / \mathrm{gram}$. Hal ini dapat dimungkinkan oleh proses pengikatan menggunakan larutan, dimana sekaligus terjadinya proses pencucian batubara dari zat-zat pengotor (impurities) yang dapat mempengaruhi nilai kalor.

Tabel 5. Nilai Kalori dalam Batubara Setelah Pengolahan dengan Sodium Karbonat

\begin{tabular}{|c|c|c|}
\hline Kons. $\mathrm{Na}_{2} \mathrm{CO}_{3}(\%)$ & $\begin{array}{c}\text { Sulfur Rata-rata Setelah } \\
(\%)\end{array}$ & $\begin{array}{c}\text { Nilai Kalori } \\
\text { (Kal/gram) }\end{array}$ \\
\hline Tanpa $\mathrm{Na}_{2} \mathrm{CO}_{3}$ & 2,41 & 5218 \\
\hline 0,05 & 2,33 & 5503 \\
\hline 0,1 & 2,32 & 5590 \\
\hline 0,5 & 2,31 & 5507 \\
\hline 1,0 & 2,29 & 5422 \\
\hline 1,5 & 2,28 & 5576 \\
\hline 2,0 & 2,23 & 5560 \\
\hline 2,5 & 2,21 & 5481 \\
\hline 3,0 & 2,21 & 5520 \\
\hline
\end{tabular}


Bila dilihat dari pengaruh penggunaan sodium karbonat sendiri dari berbagai konsentrasi $(0,05 ; 0,1 ; 0,5 ; 1,0 ; 1,5 ; 2,0 ; 2,5$ dan 3,0$)$ terhadap nilai kalor menggunakan regresi sederhana diperoleh kesimpulan bahwa konsentrasi sodium karbonat dengan nilai kalori tidak saling berkaitan secara linear (uncorrelated), dimana secara statistik nilai t hitung $<\mathrm{t}$ tabel $(0,0531<2,447)$ maka $\mathrm{H}_{0}$ diterima yang berarti tidak ada keterkaitan sebagaimana pula ditunjukkan oleh scatter diagram pada gambar 5 .

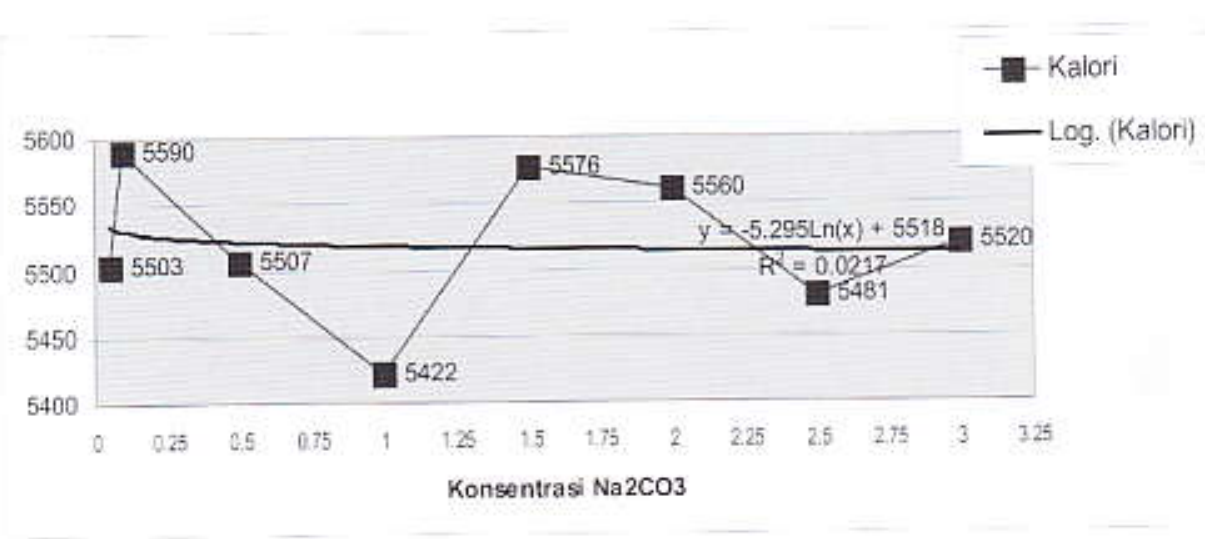

Gambar 5. Hubungan Antara Konsentrasi Sodium Karbonat dan Nilai Kalori dalam Batubara Setelah Diolah

\section{KESIMPULAN DAN SARAN}

\section{Kesimpulan}

Penggunaan sodium karbonat dapat menurunkan sulfur batubara dengan persentase penurunan yang tertinggi dalam penelitian ini sebesar $8,29 \%$ cukup menggunakan konsentrasi sodium karbonat $2,5 \%$.

\section{Saran}

Mengingat sifat sodium karbonat, $\mathrm{Na}_{2} \mathrm{CO}_{3}$ yang bila bereaksi dengan sulfur akan membentuk presipitat, maka disarankan bila terbentuk presipitat dengan segera dipisahkan dari larutan sehingga tidak bercampur dengan butiran batubara.

\section{DAFTAR PUSTAKA}

Adel L Pfeil. Sulfur Water Control (Rotten Egg Odor in Home Water Supplies. Review, Departemen of Consumen Science and Retailling. Purdue University, West Lafayette, Indiana. 2006.

Anonim. Applied Environmental Chemistry. Materi Ajar disampaikan pada program Post Graduate Dipl In Sciense. The University Of Queensland, Australia. 1999.

Anonim. Georgia Gulf Sulfur Corperation. Copyrigth, 2000.

Anonim. Analisis Dampak Lingkungan Hidup: Rencana Kegiatan Penambangan Batubara PT. KBB, 2007.

Calvert J.B. Sulfur: Moleculer Chain, Rubber and Salt Domes are Prominent in the Lore of Sulfur, Revisi terakhir. 2003.

de Nevers N., Air Pollution Control Engineering. McGraw-Hill, series in Water Resources and Environemtal Engineering, Edisi Internasional. 1995. 
Eckenfelder., Industrial Water Pollution Control. International Edition. 1989.

Imam B. Raharjo.,Mengenal Batubara (2)" Artikel IPTEK-Bidang Energi dan Sumber Daya Alam. 2006.

Sabriansyah, Purwanti. T., dan Suroto, Teknik Memproduksi dan Mengelola Bisnis Briket Batubara. Makalah disampaikan pada Pelatihan Pembuatan Briket di Dinas Perindustrian, Perdagangan dan Koperasi Bontang. 2004.

Setiaji B. Peningkatan Kualitas Batubara Muda dengan Metode Pirolisis pada Tekanan Atmosfir $\mathrm{N}_{2}, 2004$. 